\title{
Short Communication: Leptospirosis control based on eco-social factors: Modeling combination in Demak, Central Java, Indonesia
}

\author{
RR. ANGGUN PARAMITA DJATI ${ }^{1,3,8, \vartheta}$, HARYOTO KUSNOPUTRANTO ${ }^{2, \vartheta v}$, SUYUD WARNO UTOMO ${ }^{2,3,}$ \\ MATEUS SAKUNDARNO ${ }^{4,8}$, PANDJI WIBAWA DEWABRATA ${ }^{5,8,9}$, \\ HABIBURRACHMAN ALFIAN HOUZAERI FUAD ${ }^{6}$, MOCHAMMAD ARIEF WICAKSONO ${ }^{7,8}$ \\ ${ }^{1}$ Health Research and Development Unit Banjarnegara. Jl. Selomanik 16A, Banjarnegara 53415, Central Java, Indonesia. Tel./fax. +62-278-594972, \\ vemail: anggundjati@gmail.com. \\ ${ }^{2}$ Department of Environmental Health, Faculty of Public Health, Universitas Indonesia. Jl. Lingkar Kampus UI, Depok 16424, West Java, Indonesia. \\ Tel./fax.: +62-21-786 3479, ^vemail: haryoto_k@yahoo.com \\ ${ }^{3}$ School of Environmental Science, Universitas Indonesia. Jl. Salemba Raya No. 4, Kampus UI Salemba, Jakarta Pusat 10430, Jakarta, Indonesia \\ ${ }^{4}$ Faculty of Public Health and School of Graduate Studies, Universitas Diponegoro. Jl. Prof. Soedarto, Tembalang, Semarang 50275, Central Java, \\ Indonesia \\ ${ }^{5}$ Health Research and Development of Animal Borne Disease Control Unit Pangandaran. Jl. Raya Pangandaran Km 3, Pangandaran 46396, West Java, \\ Indonesia \\ ${ }^{6}$ Research Center for Climate Change, Universitas Indonesia. Jl. Margonda Raya, Depok 16424, West Java, Indonesia \\ ${ }^{7}$ Department of Anthropology, Faculty of Social and Political Sciences, Universitas Indonesia. Jl. Lingkar Kampus UI, Depok 16424, West Java, \\ Indonesia \\ ${ }^{8}$ Leptospirosis Research Network Indonesia. Jakarta, Indonesia \\ ${ }^{9}$ School of Veterinary Science, University of Queensland. Gatton QLD 4343, Queensland, Australia
}

Manuscript received: 2 September 2020. Revision accepted: 26 November 2020

\begin{abstract}
Djati RRAP, Kusnoputanto H, Utomo SW, Sakundarno M, Dewabrata PW, Duad HAH, Wicaksono MA. 2020. Short Communication: Leptospirosis control based on eco-social factors: Modeling combination in Demak, Central Java, Indonesia. Biodiversitas 21: 5818-5828. Ecological habitats and niches of leptospirosis as one of the environmental-based diseases need to be explored in an in-depth study based on eco-social analysis. The objective of this study was to develop an integrated leptospirosis control model based on eco-social factors. The location of the study was in Demak districts, Indonesia. Geographic coordinate data of cases during 2008-2018 were determined from the survey results of District Health Offices. Climatic and environmental data were obtained from Indonesian Meteorological, Climatological, Geophysical and Geospatial Information Agencies. Data on social factors were obtained by interviewing diseased persons using in-depth interview. Recorded cases and corresponding point location environmental data were then analyzed using ArcGIS and MaxEnt programs. Social network analysis was used to describe the factors involved in efforts to control leptospirosis and the relationship. The model predicted that the intervention was biological control, which had the highest leverage to reduce the morbidity rate. Health workers played an important role in efforts to control leptospirosis, although they were supported by self-supporting roles of the community. Management and control of natural and socio-environmental risk factors are very important. Combination model based on eco-social approach would be a useful tool to design and implement appropriate leptospirosis control.
\end{abstract}

Keywords: Disease, epidemiology, Leptospira, rat urine, vector

\section{INTRODUCTION}

Leptospirosis is a neglected zoonotic disease that is closely related to fairly complex environmental factors (Lau et al. 2012; Kurniawati and Nuryati 2018; Thibeaux et al. 2018). The causal agent of leptospirosis being Leptospira bacterium which when contaminates water or soil with urine from infected animals such as rats, makes it a point source for array of clinical conditions in humans such as self-limiting febrile illness to Weil's disease, manifested by jaundice, acute renal failure and bleeding (Croda et al., 2010).

This disease is prevalent across the world, both in developing and developed countries, in rural and urban areas, including Indonesia. The mortality rate from this disease is relatively low, but increases with age (Haake and Levett 2015; Taylor et al. 2015). At the jaundice level disease severity, the mortality rate can reach up to $19.1 \%$ (Haake and Levett 2015). Besides that, pulmonary hemorrhage is also associated with high fatality rate in leptospirosis (Croda et al., 2010; De Francesco Daher et al. 2017; Gulati and Gulati, 2012)

Besides being notorious as a post-flood disease, leptospirosis is also tagged as a disease caused by waterbased work and recreation (Chin 2000), which is mainly transmitted in humans through contact with bacteriacontaminated water and soil (Haake and Levett 2015). Occupational factors related to water (including swimming) and the environment with certain humidity levels as well as those related to wild/domesticated animals and pets (raising 
livestock, farming, challenging animals in laboratories, etc.) are important factors that can increase the risk of contracting leptospirosis (WHO 2007).

According to the epidemiological triangle, the onset of disease is caused by proportional imbalance between the factors of the agent (the cause of the disease), the host (human individuals), and the environment (CDC 2012). Both direct and indirect leptospirosis transmission cycles involve conglomerate of diverse biotic and abiotic factors, besides impacts of social, economic, and political aspects in such transmission are also highlighted in some studies (Vinetz et al. 2005), motivating studies in further understanding of the disease process.

In Indonesia, both humans and animals are affected by leptospirosis, and have been reported in various provinces such as South Sumatra, Bengkulu, DKI Jakarta, Banten, West Java, Central Java, East Java, East Kalimantan, South Kalimantan, and South Sulawesi. The most common cases in both humans and the principal animal reservoir viz. rats are reported from Java. Case data from the Central Java Provincial Health Office in 2010, showed several regions including Semarang, Demak, Klaten, Pati, Purworejo City, etc. showed high number of leptospirosis cases (Central Java Provincial Health Office 2008).

Demak Regency is one of the leptospirosis endemic and risk-prone districts which has geographical characteristics in the form of lowlands with incidences of flooding. In general, the number of cases reported and recorded during 2011-2016 in Demak District has decreased (Demak Health Office 2016). However, this 'pseudo' decline is correlated with gradual decrease and unreliable supply of the diagnostic tool, rapid test by Leptotek. Various efforts to control leptospirosis have been carried out by the Demak District Health Office, including screening patients, health education to the village level, technical facilitation to disease prevention and eradication officers, as well as emergency measures for managing leptospirosis with disinfectant implementation methods. Other interventions carried out starting in 2010 in the form of increased knowledge and practice of the detection of wounds on the skin and their treatment carried out in small groups.

The study from Djati et al. (2019)regarding the development of a leptospirosis control model with the system dynamics method in Demak in 2014 showed that the factors that influence leptospirosis control according to the causal loop diagram (CLD) were prevention of contact with urine from infected mice, controlling rats, reducing or managing waste properly in order to reduce food availability for mice, and treat wounds.

Though the recommendations of the above studies for leptospirosis control are fail-safe, but their realistic application is a colossal task with many practical constraints. In order to determine risk factors for leptospirosis and incorporation of ecological aspects (abiotic environmental factors, habitats, niches) including social network of the factors, social aspects of the community and health workers, applicable policies and regulations, as well as economic evaluation are needed. Identifying social linkages and incorporating such multiple eco-social factors in building validated and integrated disease control model would be helpful in identifying key factors and supporting leptospirosis control efforts comprehensively. The aim of this study is to develop an integrated leptospirosis control model based on eco-social approach.

\section{MATERIALS AND METHODS}

\section{Study area}

The location of the study was in Demak District, Central Java, Indonesia. Geographic coordinate data of cases during 2008-2018 were determined from the results of surveys of District Health Offices. Climate data and environmental data were obtained from the sources mentioned in Table 1.

\section{Preparation of data}

Raster files corresponding to the extent of study area were downloaded from the sources mentioned in Table 1. Data resolution of Land Use was KLHK (2010, 2015, and 2017), Elevation was ASTER GDEM, NDVI and NDWI were Landsat 7 (2008 and 2013) and Landsat 8 OLI (2017) and Bioclimatic variables were Worldclim (1970-2000). NDVI and NDWI rasters were cloud corrected in ArcGIS v10.

The model of leptospirosis control is based on the results of a study by Djati et al. (2019) who used the dynamic system method which was here reformulated according to the availability of data. The initial step of modeling with system dynamics on which this basic research-based is the Causal loop diagram (CLD) from the results of Djati et al. (2019), as presented in Figure 1. Determination of control scenarios was presented in graphical form.

Table 1. Abiotic environment variables

\begin{tabular}{lllll}
\hline Variables & Data & Data range & Data Source & Reference \\
\hline Land use & Land Use of KLHK 2010, 2015, 2017 & 2017 & KLHK & KLHK \\
Elevation & ASTER GDEM & NA & https://earthexplorer.usgs.gov/ & LPDAAC \\
NDVI & Landsat 7 and 8 OLI (120/065) & 2008, 2013, 2017 & https://earthexplorer.usgs.gov/ & LPDAAC \\
NDWI & Landsat 7 and 8 OLI (120/065) & $2008,2013,2017$ & $\mathrm{https} / /$ earthexplorer.usgs.gov/ & LPDAAC \\
Precipitation & Bioclimatic Variable (Bio 12) & $1970-2000$ & $\mathrm{https://www.worldclim.org}$ & Fick and \\
Temp Average & Bioclimatic Variable (Bio 1) & $1970-2000$ & $\mathrm{https://www.worldclim.org}$ & Hijmans (2017) \\
\hline
\end{tabular}

Note: KLHK: Ministry of Environment and Forestry, Indonesia; LPDAAC: Land Processes Distributed Active Archive Center 


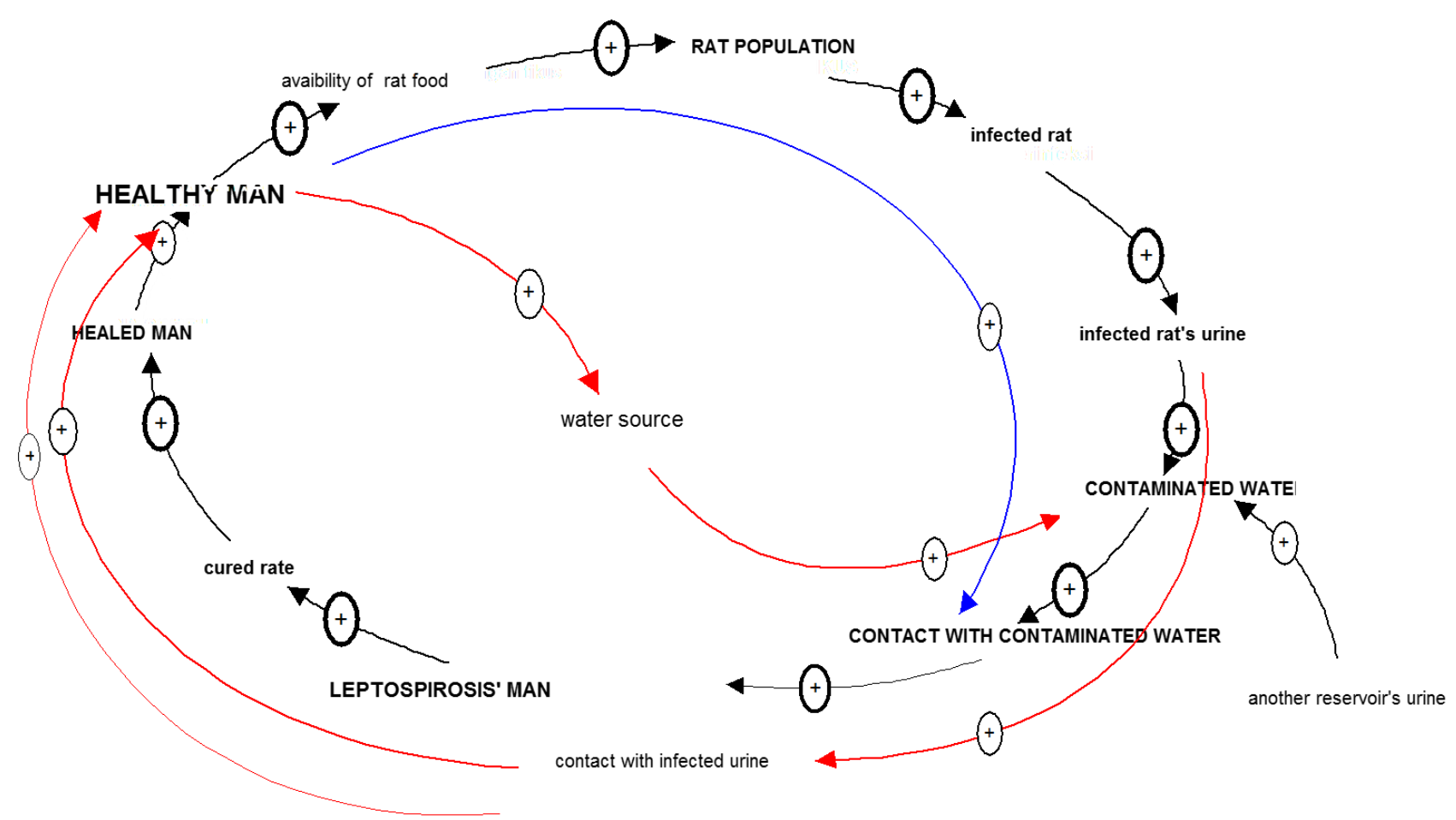

Figure 1. Causal loop diagram

Data included in the modeling was secondary data from 2008 to 2018 and the unavailable data were interpolated or extrapolated. Control stock variables used in this study were "healthy man", "leptospirosis man", and "healed man". While the uncontrolled Stock variable was "rat population" and "infected rat". As with the principles and flow of modeling analysis using the dynamics system, based on the causal loop diagram, Stock Flow diagrams were made.

\section{Procedures}

\section{MaxEnt modeling}

Maximum Entropy (MaxEnt) approach was applied for ecological niche modeling. In the beginning, coordinates of the location of reported leptospirosis cases in 2008, 2013, and 2018 were prepared in CSV format and the raster files of explanatory variables were converted into ASCII format in using ArcGIS as these two are the input data formats are read by java based MaxEnt program v3.4.0 (Phillips 2017). Then the program was run for 2008, 2013, and 2018 with setting of 134 background points, with 15 replicates with subsample replicate run type. The program was run with maximum iterations of 5000 with convergence threshold of 0,00001 There was no threshold rule applied and default prevalence was taken as 0,5 . The logistic output was analyzed and classified in ArcGIS and maps were created (Phillips 2017). Validity of the model was assessed with area under the curve (AUC) of the Receiver Operating Characteristic (ROC) metric.

\section{Social network analysis}

To describe which were the factors involved in efforts to control leptospirosis the social network analysis was used. Data on social factors were obtained by interviewing diseased persons using in-depth interviews which were validated by Focus Group Discussion, and vice versa. Furthermore, the data obtained were analyzed qualitatively by Social Network Analysis and the results of the analysis were presented in the form of a sociogram. Simulations with System Dynamic carried out with various scenarios of control efforts.

\section{RESULTS AND DISCUSSION}

\section{Prediction of the distribution of leptospirosis cases in humans based on ENM modeling using abiotic environment variables}

Based on data from the Demak District Health Office, the distribution of cases of leptospirosis in humans during the period 2008-2018 was reported in almost all districts in the region. Map of the location of case incidents is presented in Figure 2.

There were some cases that were reported in the Health District Office, but due to unclear address, transfer of handling health center staff and limited resources their further details could not be found.

There are several variables associated with the location of the case, among others land use, land wetness, vegetation density, precipitation, and average temperature. 
Modeling results indicate several conditions. The results of modeling in 2008, 2013, and 2018 are presented in Figure 3.

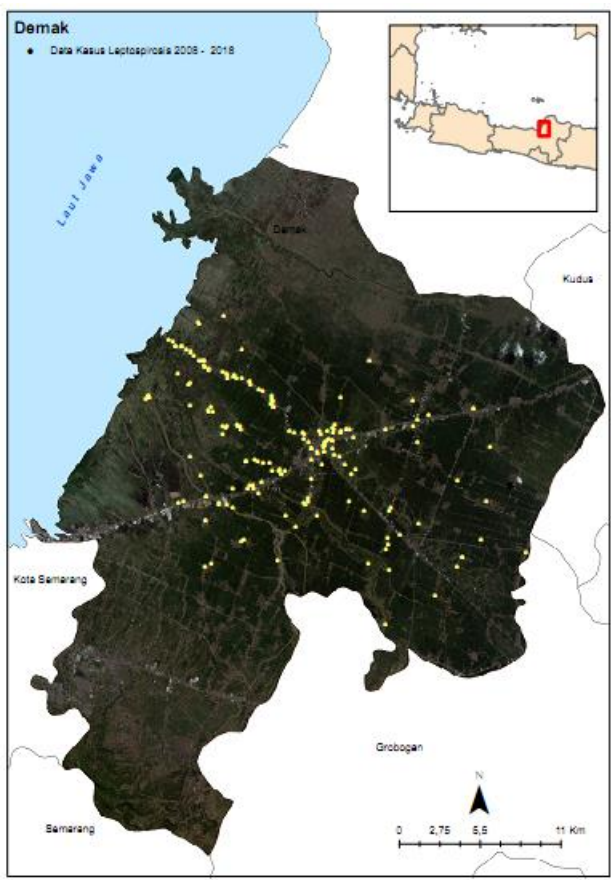

Figure 2. Distribution of leptospirosis cases on human in Demak (Central Java, Indonesia), 2008-2018

The model predicted that the maximum distribution of leptospirosis was explained by land-use variable $(69,1 \%)$. Validity of model indicated by AUC was 0,890 The model is said to be more valid the greater the AUC number. The maximum and average modeling results after 14 stages of repetition for 10 years (2008-2018) are presented in Figure 4.

The greater risk of leptospirosis is illustrated by changes in color gradations that are increasingly towards red. Increasingly heading to coastal locations or lowlands shows that the incidence of leptospirosis cases in humans is increasing.

\section{Leptospirosis handling through its social network analysis}

In the Demak area, Morodemak Village of Bonang Sub District was chosen as study site. This village is the one of working areas of the Puskesmas (Public Health Center) Bonang I. The reason for choosing the location was the level of endemicity and the high number of cases compared to other villages in Bonang for the past 10 years in Demak Regency based on data of Demak Health Office.

Interviews were conducted with the informants who played pivotal roles in controlling and managing leptospirosis in Puskesmas Bonang I such as (i) Coordinators for Disease Control and Eradication (P2P) at Puskesmas Bonang I, (ii) Village Midwives/Bidan Desa, (iii) Surveillance Officers, (iv) Officials of District Health Office Demak, (v) Puskesmas staff, (vi) Officials of Agriculture Department Demak and (vii) Hospital staff. An overview of informants and the relationships between them are presented in Figure 5.

One interesting fact from the sociogram picture above is the presence of the hospital which actually has major role in record-keeping while its report disseminating role needs to be bolstered. In fact, in an ideal structure, reports on the findings of cases of leptospirosis should be obtained from the village midwife or surveillance, which is then forwarded to the Puskesmas, District Health Office, and then to the hospital. Patients who report themselves directly to hospitals may not be helpful to channelization of leptospirosis data which would have strengthened dynamics in identification of handling and control of leptospirosis through social network approach.
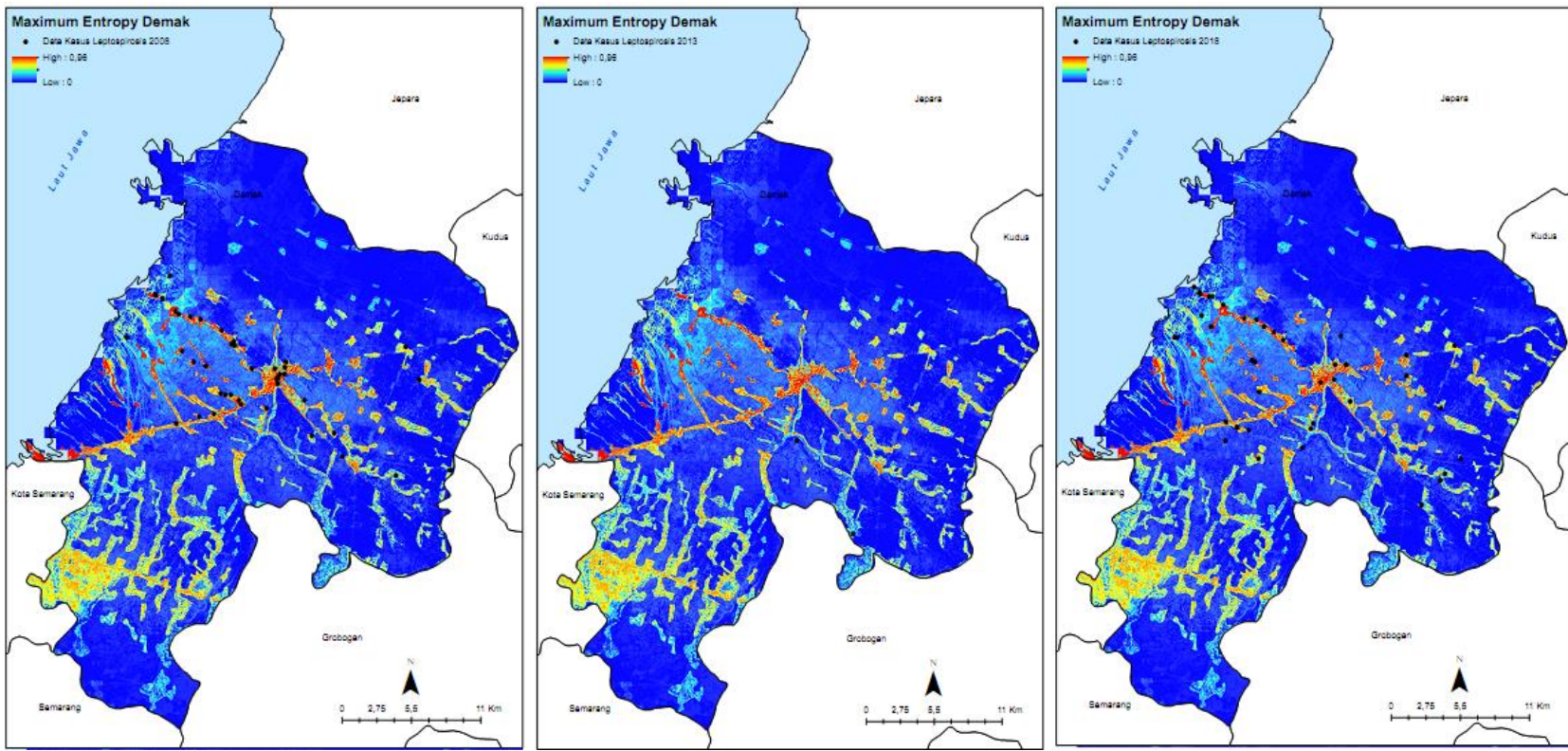
Figure 3. Distribution leptospirosis Cases on Human based on Maximum Entropy in Demak (Central Java, Indonesia), 2008,2013 and 2018
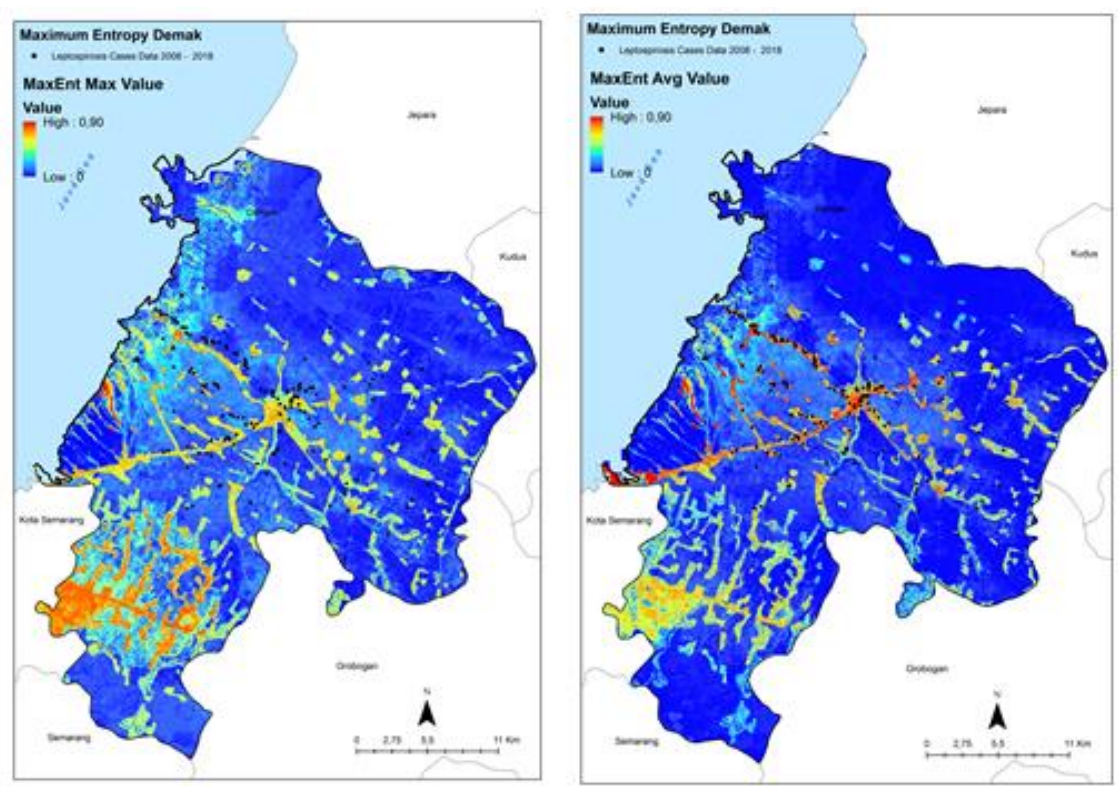

Figure 4. Distribution leptospirosis cases on human-based on Maximum Entropy in Demak (Central Java, Indonesia) from $2008-2018$. Note: A = Maximum; B = Average

During the study, a remarkable biological control of rats was noted in Tlogoweru village where there is practice of Owl breeding and its use as biologically controlling rats (Figure 6). Based on data from District Health Office, there have never been any cases of leptospirosis during the last 10 years in Tlogoweru. The principle factors in this sociogram are: (i) Owl breeders, (ii) the Agriculture Service, (iii) the Forest Service, (iv) the Health Service.

Figure 5 sociogram indicates following: (i) Awareness on threat of leptospirosis related to animal husbandry, (ii) Delegation of Puskesmas tasks at the local/community level, (iii) Report preparation and submission to the Puskesmas on the findings of suspected leptospirosis cases, (iv) Forwarding the report made by the village midwives/surveillances to the District Health Office, (v)
Awareness activities to the public about the prevention and treatment of leptospirosis, (vi) Keeping record of cases of incoming leptospirosis patient cases.

Figure 6 sociogram indicates following: (i) An owl breeder needs permission from Forest Department to own owl, (ii) The agriculture office needs the services of Owl breeder and his owls to eradicate rat pests in the agricultural fields

The Department of Health has not adopted the practice of taking the service of owl breeders in similar line to that of Department of Agriculture for controlling rats through Owls. Taking cue from the success of Agriculture Department-Owl Breeder participation, Health officials need to conceptualize biological control of Rats as leptospirosis vectors through owls.

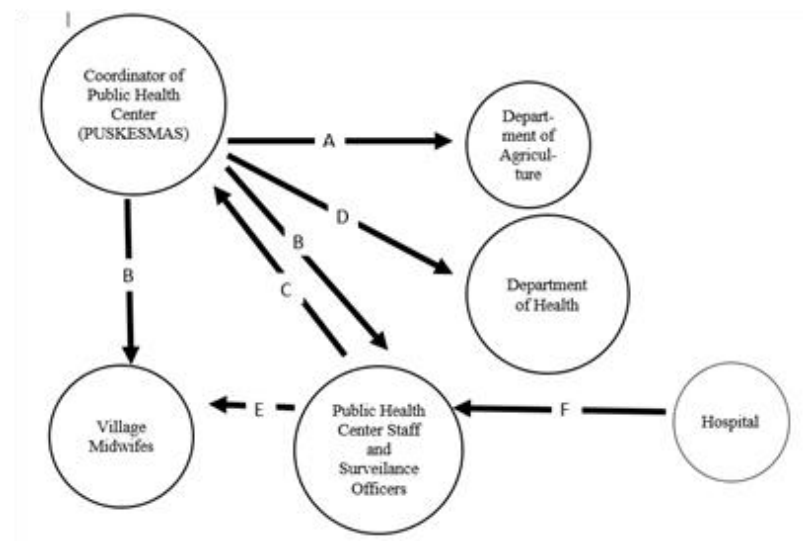

Figure 5. Social network mapping in leptospirosis handling mechanism, Bonang, Demak, Central Java, Indonesia

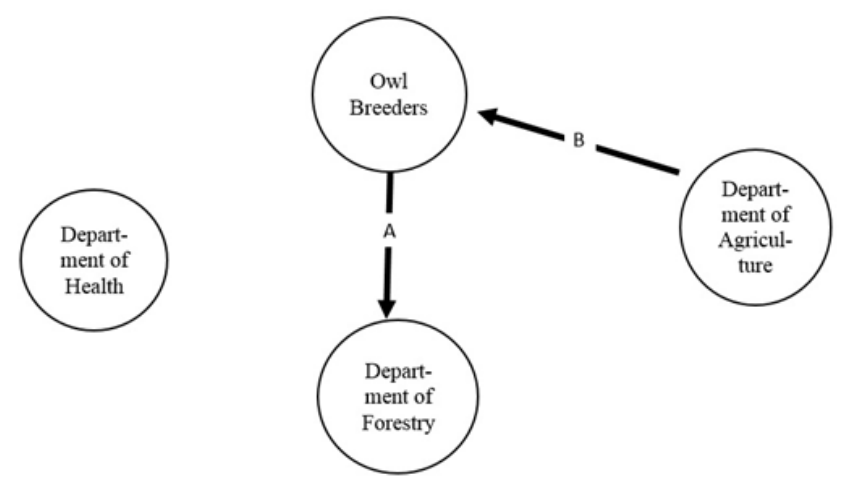


Figure 6. Social network mapping in leptospirosis handling mechanism, in the context of owl (Tyto alba) breeding, Tlogoweru, Demak, Central Java, Indonesia

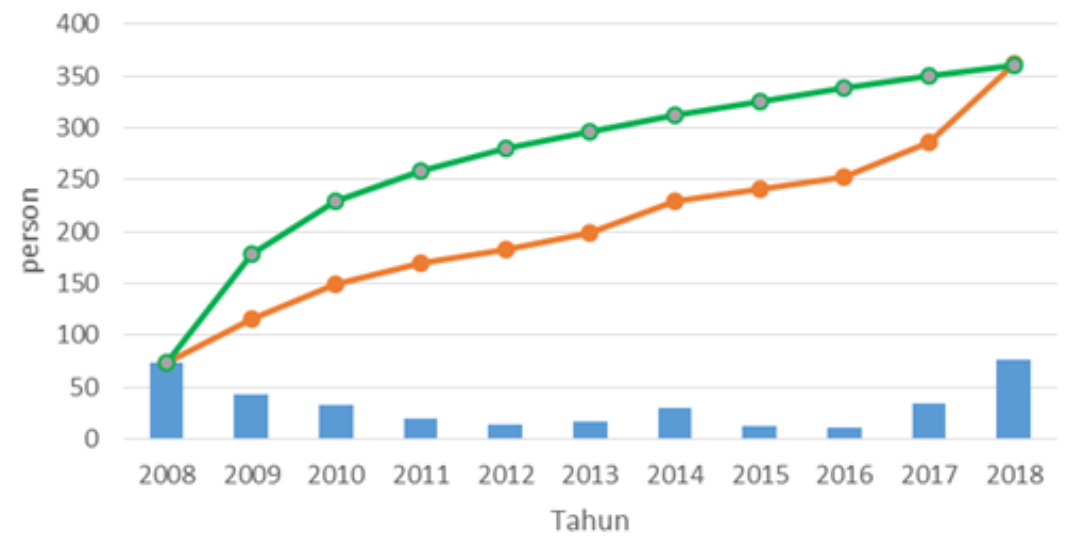

Human cases $\longrightarrow$ Accumulation $\quad \longrightarrow$ Result Simulation

Figure 7. Comparison of real data (orange) with model simulation (green)

\section{Scenarios of control efforts by system dynamics}

The causal loop diagram generated from Djati (2014) study, was re-tested using the latest time-series data for leptospirosis cases in Demak. The graph showed a pattern that was still the same as the graph produced in previous studies. Next, the graph was visually compared with the latest simulation graph. The model simulated as a trendline. Researchers applied several scenarios of control measures to reduce the accumulation rate of leptospirosis cases predicted in the previous simulation. Results of real data simulation on the leptospirosis control model during 20082018 are presented in Figure 7.

Figure 7 showed that the model was valid based on visual validation. The behavior pattern of the occurrence of leptospirosis (accumulation) based on existing data from 2008 - 2018 in Demak Regency shows a pattern of behavior similar to the pattern of behavior of graphs of the model simulation results. Visually, the model is called valid if the behavior (form graph) model simulation results to Stock variables approach or resemble graphic form of real simulation results based on reference data in time series. Based on the results of the model reformulation using the data obtained in this study, rodent control is one of the scenarios that still has leverage that is easy to be compared to other scenarios.

\section{Discussion}

Ecological niche modeling is an appropriate method used to predict the distribution and incidence of disease with limited data. This method is used in general to see the existence and distribution and spatial prediction of species. The epidemiology of a disease related to ecological factors requires different ways of explanation, taking into account active role of environmental factors in epidemiological triangle. In some zoonotic cases that have limited data or in cases of new diseases, ecological niche modeling is chosen as an appropriate method with results that can be visualized as maps and graphic response curves that are easy to understand.

Leptospirosis is a disease with a lot of differential diagnosis due to nonspecific symptoms that are not detected or confirmed correctly. This causes leptospirosis to be reported too late, or not reported because it is not detected or confirmed correctly. Several recent studies have used modeling using the Ecological Niche Modeling (ENM) approach to try to overcome the lack of available data on cases of certain diseases, including leptospirosis) (Sánchez-Montes, et al., 2015; Zhao et al., 2016) . The basis of the prediction made is the identification of factors involved in the ecological niche.

ENM is a technique that aims to estimate the ecology of species by describing environmental landscape factors through analyzing the relationship between data on the occurrence of biological phenomena and the collection of raster type geospatial data (Bodbyl-Roels et al. 2011). Among the prime advantages of ENM, the foremost is it can describe the distribution of cases accompanied by related environmental factors and also other biotic factors, namely humans (social and mobility), vectors and reservoirs of the disease. In addition, by using this method a geographic prediction of the distribution of diseases, including those with relatively low data can be carried out, so that through the resultant map appropriate and efficient intervention efforts could be planned.

MaxEnt has one of the maximum predictive accuracies among contemporary modeling techniques (Phillips and Dudík 2008). The advantage of this method is that it can work with limited samples and presence-only data. The purpose of using this method in this research is a tool for estimating the distribution. Jaynes (1957) cited by Escobar and Craft (2016), states that the use of MaxEnt is the best way to ensure an approach that has constraints on the 
absence of distribution data. Hernandez et al. (2006) cited by Escobar and Craft (2016) states that this method has the highest spatial accuracy and concordance for the small sample size category (Escobar and Craft 2016).

Using the standard validation test of the ENM model by looking at the area under the curve (Area under the Curve/AUC) on the Receiver Operating Characteristic (ROC) metric has limitations if it is used to predict the distribution of certain diseases. Therefore, alternative test methods can also be used such as Akaike information criterion (Warren and Seifert 2011), cumulative binomial probability test (CBP), and Partial ROC (Escobar and Craft 2016).

Study of spatial modeling analysis of environmental factors and distribution of leptospirosis cases with overlay process to determine the level of leptospirosis vulnerable zone in Demak have been done (Rahayu et al. 2018). The study had also involved social factors such as poor sewerage conditions and poor waste disposal facilities. On the basis of available data spatial analysis shows the correlation or distribution of disease events that have occurred or are currently occurring. However, this analysis cannot demonstrate the prediction of unreported events (pseudo-absence data) or future events (future projections), which can be overcome in ENM (Phillips et al. 2004).

As leptospirosis is not concerned with all areas, it is often neglected as a disease, and earlier overlay process spatial analysis has not adequately described the real conditions. Through maximum entropy and ENM's proven approach, a more comprehensive picture can be obtained for formulating effective control effort plan.

The description of the ecological structure at the study site (in this case several Puskesmas work areas in Demak, Central Java) is indeed important to discuss the causes, disease control, and management of patients and outbreaks of leptospirosis. However, when discussing the handling mechanism, one should not forget the factors involved in the handling process. This is where the social network approach is used to look at a map of factors in handling diseases and leptospirosis patients. The explanation for handling leptospirosis through the social network approach here was based on interviews conducted with concerned informants in Demak, especially at the micro-level or at the community level. It should be noted that the social networking approach used here is based on categorical factors. Two facts to consider in reading a sociogram are: (i) the binding of the content, (ii) the flow or direction of the arrow from that content.

One of the methods used to determine the leptospirosis control effort that has been done is system dynamics. According to the definition of Sterman (2004) cited by Soesilo and Karuniasa (2014), system dynamics is a method for studying complex systems, based on nonlinear theory, dynamics, and feedback control. The characteristics of system dynamics include complexity, dynamics, nonlinearity, and feedback. There are seven steps that need to be taken to achieve dynamic system goals as a method, namely observation of actual systems, structuring the problem, making models, validating models, simulating business as usual scenario models, simulating intervention scenario models, and interpreting and using simulation model results (Soesilo and Karuniasa 2014). Although positive reservoir location cannot be included in the spatial modeling in this study, in modeling using a dynamic system, data can be entered in the form of reservoir density numbers in the location of the study. The data is in the form of rat density figures, as the main reservoir of leptospirosis, obtained from the results of field surveys. This rat density figure is calculated based on the number of rat caught from all the traps set in a certain time period. Based on the results of a survey by the Banjarnegara Animal Sourced Disease Control and Research Center in 2014 , it is known that the catch success rate is $6-27 \%$ in three different villages that have high rates of leptospirosis cases in humans. Rodent control, especially of rat, is still one of the most effective efforts both when viewed based on the amount of leverage according to dynamic system model that is combined with the efficiency of resources used and ease of implementation in the field. In the system dynamic method, the presence of domestic waste in the Causal Loop Diagram also contributing to increasing the rat population. This also means it could be increasing the number of infected rats.

System dynamics can be used for social good, include healthcare. In particular, they illustrate how system dynamics can effectively capture key elements of complex dynamic systems. Then, it allows managers to understand the behavior of such environments and make better decisions over time (Gonçalves 2019)

The combination of the overall modeling results taking into account the diversity of ecological and social aspects in this study showed that efforts to control leptospirosis can be done efficiently so as to reduce the incidence of cases for the next few years. Social aspects that need to be considered, not only the importance of communication and education across sectors and communities, but also need to continuously maintain a fast reporting system and flow by considering the potential of each region. The breeding of owls as one of the best efforts to control leptospirosis in endemic areas with rice fields, from the combined modeling analysis is one of the recommendations from this study for consideration.

Although the type of modeling used in this analysis has the advantage of being suitable for diseases with limited data, if it is applied to modeling disease incidence where the data is more complete, the validity and accuracy will be better. Analysis of the transmission cycle using a dynamic system is one of the appropriate modeling methods for leptospirosis, which has many factors and related components in it. The more comprehensive the data obtained, the more accurate modeling using this system will be.

In conclusion, efforts of health workers have an important role in controlling leptospirosis, although to be supported by self-supporting roles of the community. However, it does not always mean that only the health sector must work alone to overcome the problem of leptospirosis. As demonstrated in several studies, incidence and spread of leptospirosis have much dependence upon environmental factors. These factors include natural, social, 
and fostered environmental components that influence the unique epidemiological setting of leptospirosis. There are characters that are generally accepted in all the affected regions, but there are also unique are specific environmental characteristics that determine the incidence and distribution of leptospirosis in a particular area. Therefore, other sectors do need attention and cooperation in various efforts to control leptospirosis. One of them is the environment sector, which has so far not been linked to various leptospirosis control programs in the region, as well as the health sector which may need to involve in biological management of disease vectors. Pest control of Rats is a cause of concern and needs to be prioritized and concerted together between multiple sectors. One Health approach is needed in an effort to connect actors and related sectors. Management and control of natural and social environmental risk factors are very important. Combination model based on eco-social approach was a useful tool to predict the efficiency of leptospirosis control.

\section{ACKNOWLEDGEMENTS}

This article is the result of study funded by PITMA A organized by Direktorat Riset \& Pengabdian Masyarakat (DPRM), Universitas Indonesia, Depok, Indonesia.

\section{REFERENCES}

Bodbyl-Roels S, Peterson T, Xiao X. 2011. Comparative analysis of remotely-sensed data products via ecological niche modeling of avian influenza case occurrences in Middle Eastern poultry. Intl J Health Geogr 10 (1): 10-21. DOI: 10.1186/1476-072X-10-21.

CDC. 2012. Principles of Epidemiology in Public Health Practice: An Introduction to Applied Epidemiology and Biostatistics. 3rd ed Centers for Disease Control and Prevention, Atlanta, USA.

Central Java Provincial Health Office. 2008. Leptospirosis Cases Report. Provincial Government of Central Java, Semarang. [Indonesian]

Chin J (ed.). 2000. Control of Communicable Diseases Manual. 17th ed. American Public Health Association, Washington, DC.

Croda J, Neto AN D, Brasil RA, Pagliari C, Nicodemo AC, Duarte MIS. 2010. Leptospirosis pulmonary haemorrhage syndrome is associated with linear deposition of immunoglobulin and complement on the alveolar surface. Clin Microbiol Infect 16 (6) 593-599. DOI: 10.1111/j.1469-0691.2009.02916.x.

De Francesco Daher E, de Carvalho GSG, de Sousa Soares D, Mendes MH, Parente Filh SLA, Rocha, HAL, da Silva Junior GB. 2017. Changing patterns in leptospirosis: a three-decade study in Brazil. Intl J Infect Dis 60: 4-10. DOI: 10.1016/j.ijid.2017.04.023.

Demak Health Office. 2016. Leptospirosis Cases Report. District Government of Demak, Demak. [Indonesian]
Djati AP, Ramadhani T, Pramestuti N, Priyanto D, Handayani T, Budhi Soesilo TE. 2019. System dynamic model of leptospirosis control in demak, indonesia, 2014. Indian J Public Health Res Dev 10 (3): 753 764. DOI: 10.5958/0976-5506.2019.00593.X.

Escobar LE, Craft ME. 2016. Advances and limitations of disease biogeography using ecological niche modeling. Front Microbiol 7 (AUG): 1-21. DOI: 10.3389/fmicb.2016.01174.

Gonçalves P. 2019. System dynamics for social good. Producao 29. DOI: 10.1590/0103-6513.20190062.

Gulati S Gulati, A. 2012. Pulmonary manifestations of leptospirosis. Lung India 29 (4): 347-353. DOI: 10.4103/0970-2113.102822.

Haake DA, Levet PN. 2015. Leptospirosis in Humans. Curr Top Immunol 387: 65-97. DOI: 10.1007/978-3-662-45059-8

Kurniawati RD, Nuryati S. 2018. The Correlation between physical environmental factors and the occurrence of Leptospirosis. Jurnal $\begin{array}{llll}\text { Kesehatan Masyarakat } 14 & \text { (2): 223-230. DOI: }\end{array}$ 10.15294/kemas.v14i2.13527.

Lau CL, Dobson AJ, Smythe LD, Fearnley EJ, Skelly C, Clements ACA, Weinstein P. 2012. Leptospirosis in American Samoa 2010: Epidemiology, environmental drivers, and the management of emergence. Am J Trop Med Hyg 86 (2): 309-319. DOI: 10.4269/ajtmh.2012.11-0398.

Phillips S. 2017. A Brief Tutorial on Maxent. AT\&T Research. http://biodiversityinformatics.amnh.org/open_source/maxent/

Phillips SJ, Dudík M, Schapire RE. 2004. A maximum entropy approach to species distribution modeling. Proceedings, Twenty-First Int Conf Machine Learn 2004: 655-662. DOI: 10.1145/1015330.1015412.

Phillips SJ, Dudík M. 2008. Modeling of species distribution with Maxent: new extensions and a comprehensive evaluation. Echography 31: 161-175. DOI: 10.1111/j.2007.0906-7590.05203.x.

Rahayu S, Sakundarno Adi M, Dian Saraswati L. 2018. Mapping of leptospirosis environmental risk factors and determining the level of Leptospirosis vulnerable zone in Demak District using remote sensing image. E3S Web of Conf 31: 06003. DOI: $10.1051 /$ e3sconf/20183106003.

Sánchez-Montes S, Espinosa-Martínez DV, Ríos-Muñoz CA, BerzunzaCruz M, Becker I. 2015. Leptospirosis in Mexico: Epidemiology and potential distribution of human cases. PLoS ONE 10 (7) 1-16. DOI: 10.1371/journal.pone.0133720.

Soesilo B, Karuniasa M. 2014. Permodelan System Dynamics untuk Berbagai Bidang Ilmu Pengetahuan, Kebijakan Pemerintah dan Bisnis. Jakarta: Lembaga Penerbit Fakultas Ekonomi Universitas Indonesia, Depok. [Indonesian]

Taylor AJ, Paris DH, Newton PN. 2015. A Systematic Review of The Mortality from Untreated Leptospirosis. PLoS Negl Trop Dis 9 (6): 119. DOI: 10.1371/journal.pntd.0003866

Thibeaux R, Girault D, Bierque E, Soupé-Gilbert ME, Rettinger A, Douyère A, Goarant C. 2018. Biodiversity of environmental Leptospira: Improving identification and revisiting the diagnosis. Front Microbiol 9 (MAY): 1-14. DOI: 10.3389/fmicb.2018.00816.

Vinetz JM, Wilcox BA, Aguirre A, Gollin LX, Katz AR, Fujioka RS, Chang H. 2005. Beyond disciplinary boundaries: Leptospirosis as a model of incorporating transdisciplinary approaches to understand infectious disease emergence. EcoHealth 2 (4): 291-306. DOI: 10.1007/s10393-005-8638-y.

Warren DL, Seifert SN. 2011. Ecological niche modeling in Maxent: the importance of model complexity and the performance of model selection criteria. Ecol Appl 21 (2): 335-342. DOI: 10.2307/29779663 WHO. 2007. Leptospirosis - Laboratory Manual, WHO, Geneva.

Zhao J, Liao J, Huang X, Zhao J, Wang Y, Ren J, Ding F. 2016. Mapping risk of leptospirosis in China using environmental and socioeconomic data. BMC Infect Dis 16 (1): 343. DOI: 10.1186/s12879-016-1653-5. 